Jumal Penditian danEvaluas Penddikan

\title{
ANALISIS ASESMEN FORMATIF FISIKA SMA BERBANTUAN KOMPUTER
}

\author{
Sentet Kusain \\ Jurusan Fisika FMIPA UM, 2012. \\ skusairi@yahoo.com
}

\begin{abstract}
Abstrak
Penelitian ini bertujuan untuk: (1) mengembangkan model analisis asesmen formatif Fisika (AAFF) berbantuan komputer, (2) menemukan kharakteristik model analisis asesmen formatif Fisika berbantuan komputer, (3) menentukan kelayakan model analisis asesmen formatif Fisika berbantuan komputer. Penelitian yang dilakukan merupakan penelitian pengembangan (rearch and dedopment), dengan desain pembelajaran (instructional desig) oleh D ick dan Carey. Penelitian melibatkan beberapa Sekolah Menengah Atas di Kota Malang mulai Maret 2010 sampai dengan September 2010. Hasil pengembangan merupakan model AAF berbantuan computer, dengan karakteristik (1) Model dapat menggali kelemahan dan kesulitan belajar siswa, (2) Model analisis dapat memberikan umpan balik pada siswa tentang hasil tes, (3) Model AAFF dapat menghasilkan pengelompokan siswa berdasarkan kesulitan belajar atau siswa yang menderita miskonsepsi atau kesulitan tertentu, (4) model dapat menentukan siswa yang menjawab tidak konsisten.
\end{abstract}

Kata kunci: analisisasemenfomatif fisika (AAFF) 


\title{
A COMPUTER-ASSISTED ANALYSIS OF PHYSICS FORMATIVE ASSESSMENT FOR SENIOR HIGH SCHOOLS
}

\author{
Sentat Kusain \\ Jurusan Fisika FMIPA UM, 2012. \\ skusairi@yahoo.com
}

\begin{abstract}
The objectives of this study are: (1) to develop a model for a computer-assisted analysis of physics formative assessment, (2) to find out the characteristics of the final product of the model, (3) to assess the feasibility of the final product of the model. This was a research and development study employing the instructional design by Dick and Carey. It involved several senior high schools in Malang City, conducted from March 2010 to September 2010. The result of the development is a model for a computer-assisted AAF with characteristics as follows. (1) The model can identify students' learning weaknesses and difficulties. (2) The model of the analysis can give students feedback about test results. (3) The AAFF model can result in students' grouping based on learning difficulties or students with misconceptions or learning difficulties. (4) The model can detect students answering inconsistently.
\end{abstract}

Keywords: analysis of physics fomativeassessment

\section{Pendahuluan}

Kualitas pembelajaran ditentukan salah satunya oleh kualitas asesmen yang dilakukan oleh guru dalam proses pembelajaran. Kegiatan asesmen dapat membantu guru memahami kekuatan dan kelemahan yang dialami oleh siswa dalam belajar. Semakin berkualitas kegiatan asesmen pembelajaran, pemahaman guru akan kelemahan dan kekuatan siswa dalam mempelajari materi tertentu semakin baik. D engan melaksanakan asesmen 
yang berkualitas dan menganalisisnya untuk mendapatkan informasi tentang kelemahan belajar siswa, guru memiliki acuan untuk mengambil keputusan yang efektif dalam proses pembelajarannya. A sesmen juga dapat memberikan informasi pada siswa tentang kemajuan belajarnya sehingga siswa dapat memperbaiki perilaku belajarnya.

Pentingnya peranan asesmen dalam pembelajaran telah ditekankan secara eksplisit dalam Peraturan Menteri Pendidikan Nasional nomor 20 tahun 2007 tentang Standar Penilaian Pendidikan. Pada bagian E tentang penilaian oleh pendidik, disebutkan bahwa penilaian hasil belajar oleh pendidik harus dilakukan secara berkesinambungan, bertujuan untuk memantau proses dan kemajuan belajar peserta didik, serta untuk meningkatkan efektivitas kegiatan pembelajaran. Beberapa langkah kegiatan penilaian diantaranya adalah sebagai berikut. (1) mengembangkan indikator pencapaian $\mathrm{KD}$ dan memilih teknik penilaian yang sesuai pada saat menyusun silabus pembelajaran, (2) mengembangkan instrumen dan pedoman penilaian sesuai dengan bentuk dan teknik yang dipilih, (3) melaksanakan tes, pengamatan, penugasan, dan/atau bentuk lain yang diperlukan, (4) mengolah hasil penilaian untuk mengetahui kemajuan hasil belajar dan kesulitan peserta didik, (5) mengembalikan hasil pemeriksaan pekerjaan peserta didik disertai balikan/komentar yang mendidik, (6) memanfaatkan hasil penilaian untuk perbaikan pembelajaran (Permendiknas No 20, 2007).

Dalam pembelajaran Fisika di SMA, asesmen formatif dan analisis untuk untuk mendapatkan informasi kekuatan dan kelemahan belajar siswa sangat diperlukan mengingat karakteristik materi pelajaran Fisika yang berjenjang. Materi pelajaran pada bagian awal merupakan prasyarat untuk mempelajani materi pelajaran berikutnya. Jika seorang siswa mengalami kesulitan pada materi awal dan tidak mendapatkan bantuan, besar kemungkinan siswa akan mengalami kesulitan pada saat mempelajari materi berikutnya. Hal inilah yang menyebabkan siswa berpersepsi bahwa Fisika hanyalah kumpulan rumus yang harus dihapalkan dan dimanfaatkan ketika berhadapan dengan soal ujian. Siswa tidak memahami esensi konsep Fisika sehingga belajar Fisika tidak bermakna dalam kehidupannya. Jika kesulitan tidak mendapatkan penanganan, prestasi belajar siswa menjadi rendah.

\section{0 - Jumal Penditian danEvaluasi Pendidkan Edisi D ies Natalis ke-48 UNY}


Asesmen formatif dalam pembelajaran Fisika pada saat ini belum terlaksana dengan optimal. Beberapa hal yang menyebabkan kurang optimalnya pelaksanaan asesmen formatif yaitu (1) perencanaan dan pelaksanaan asesmen formatif membutuhkan ketrampilan, sementara belum semua guru mendapatkan pelatihan profesional untuk melaksanakan teknik-teknik asesmen formatif, (2) pengembangan instrumen, implementasi, dan analisis data-data tes formatif memerlukan waktu, sementara beban tugas guru terutama guru yang telah tersertifikasi sangat tinggi, (3) jumlah kelas dan jumlah siswa setiap kelas yang cukup besar. Jumlah siswa per kelas berkisar antara 30-40 siswa. Diperlukan waktu ekstra untuk memberikan perhatian kepada siswa secara individual dalam pelaksanaan asesmen, (4) belum tersedia instrumen baku untuk melaksanakan asesmen formatif, (5) belum tersedianya perangkat untuk menganalisis data-data asesmen.

D engan adanya keterbatasan instrumen dan perangkat analisis yang dihadapi guru dalam melaksanakan asesmen formatif, pelaksanaan asesmen formatif kurang dapat memberikan dampak yang signifikan dalam proses pembelajaran. Guru tidak dapat memperoleh informasi tentang kekuatan dan kelemahan belajar siswa, sebagai akibatnya gunu belum memperoleh pedoman yang jelas dalam menindak lanjuti hasil pembelajaran. D emikian juga dengan siswa, siswa tiak mendapatkan umpan balik yang memadai tentang hasil belajarnya. Siswa tidak memiliki acuan untuk memperbaiki proses dan hasil belajarnya.

\section{Asesmen Formatif dan Analisisnya}

Asesmen merupakan kegiatan pengumpulan informasi dalam rangka pengambilan keputusan-keputusan berdasarkan informasi. D alam konteks pembelajaran, asesmen berarti pengumpulan berbagai informasi tentang proses dan hasil belajar siswa dalam rangka menentukan keputusankeputusan yang perlu dilakukan dalam pembelajaran (Anderson, 2003: 4). Beberapa karakteristik asesmen dalam pembelajaran antara lain adalah sebagai berikut: (1) Asesmen dimulai dengan pengumpulan berbagai informasi tentang siswa dalam pembelajaran; (2) Dalam kegiatan asesmen dilakukan analisis dan interpretasi terhadap data dan informasi yang 
berhasil dikumpulkan; (3) Interpretasi menghasilkan keputusan-keputusan tentang pembelajaran; (4) Terdapat tindak lanjut terhadap keputusan yang dihasilkan; (5) A sesmen dilakukan secara berkelanjutan.

Asesmen merupakan bagian yang tidak terpisahkan dari proses pembelajaran. Popham (1995: 7) menyatakan beberapa alasan tentang pentingnya pemahaman dan pelaksanaan asesmen diantaranya adalah sebagai berikut: (1) Asesmen merupakan piranti untuk mendiagnosis kekuatan dan kelemahan siswa dalam proses pembelajaran; (2) Asesmen berguna untuk memonitor kemajuan siswa; (3) Asesmen membantu menentukan tingkatan siswa; (4) Asesmen juga dapat menentukan efektivitas pembelajaran yang telah dirancang. Selain beberapa alasan klasik tersebut, alasan peningkatan kualitas pembelajaran merupakan salah satu alasan melaksanakan asesmen.

Berkaitan dengan ragam kegiatan asesmen yang dilakukan dalam pembelajaran, asesmen dapat dipilah menjadi dua bagian besar yakni asesmen sumatif dan asesmen formatif. Asesmen sumatif merupakan kegiatan yang menghasilkan angka dan tingkatan yang dimanfaatkan untuk menentukan penampilan siswa. Pada akhirnya keputusan-keputusan pada asesmen sumatif digunakan untuk menentukan penghargaan pada siswa di akhir masa pembelajaran. Di lain pihak, asesmen formatif merupakan kegiatan yang memberikan umpan balik terhadap pembelajaran yang dilakukan oleh siswa. William (Boyle\&Fisher, 2007: 23) menyebut asesmen untuk tujuan formatif sebagai assessment for leaming sedangkan asesmen sumatif disebut sebagai assessment of leaming

Cowie\&Bell (2002: 6) mendefinisikan asesmen formatif sebagai proses yang digunakan oleh guru dan siswa dalam mengenali dan merespon belajar siswa dalam rangka meningkatkan belajarannya dalam proses pembelajaran. Asesmen formatif membantu guru dalam menggambarkan kemajuan belajar siswa dan menginformasikan keputusan tentang langkah selanjutnya dalam pembelajaran. Jadi informasi asesmen formatif dapat digunakan oleh guru dan siswa untuk memodifikasi cara belajar atau cara mengajarnya dengan harapan mendapatkan hasil yang lebih efektif. Popham (2008: 5) mendefinisikan asesmen formatif sebagai berikut. "Fommative assessment is a planned process in which assessment-dicited evidence of 
students' status is used by teachers to adjust their angainginstructional proedures or by students to adjust their aument lemingtadies".

Beberapa pengertian tentang asesmen formatif yang telah dikemukakan memiliki beberapa kesamaan diantaranya: (1) Asesmen formatif merupakan proses yang dilakukan dalam pembelajaran; (2) Hasil asesmen formatif tidak saja digunakan oleh guru tetapi juga dilakukan oleh siswa; (3) Asesmen formatif memberikan umpan balik terhadap proses belajar siswa dan proses pembelajaran yang dilakukan oleh guru; (4) Umpan balik yang diberikan oleh asesmen formatif akan berguna bagi siswa dan guru untuk melakukan pengaturan-pengaturan sehingga belajar dan pembelajaran dapat mencapai tujuan kurikulum.

Implementasi asesmen formatif dalam pembelajaran dapat dipilah menjadi asesmen formatif yang bersifat informal dan asesmen formatif yang bersifat formal. Asesmen formatif yang bersifat formal dilakukan misalnya dengan meminta siswa untuk mengerjakan tes, kuis, mengembangkan tulisan atau karya yang lain. Asesmen informal merupakan kegiatan-kegiatan dalam pembelajaran yang dipilih oleh guru untuk menguak informasi dari siswa. Kegiatan tanya jawab di kelas, meminta siswa mengkomentari pendapat guru, wawancara, rekaman pembelajaran merupakan beberapa contoh asesmen formatif yang bersifat informal.

Asesmen formatif formal dan informal masing-masing memiliki kelebihan dan kekurangan. Beberapa kelebihan asesmen formatif formal adalah lebih fair bagi siswa. Dalam asesmen formatif formal siswa merasakan langsung bahwa mereka sedang diases, asesmen formal juga memiliki kriteria skoring yang jelas, dan akan memotivasi siswa jika mereka berhasil. Namun seringkali asesmen formatif formal juga dapat menyebabkan stres jika siswa mengalam kegagalan. Asesmen formal juga membutuhkan persiapan yang lebih panjang dan memerlukan waktu untuk menganalisis hasil-hasilnya. Kelebihan asesmen formatif informal adalah dapat dilaksanakan dalam proses pembelajaran dan dalam suasana santai sehingga siswa tidak mengalami stres, mudah dipersiapkan, dan seringkali menghasilkan data-data yang lebih valid langsung dari siswa. Kegiatan asesmen formatif formal melalui komunikasi guru-siswa di kelas dapat 
langsung dianalisis dan diberikan umpan balik oleh guru serta memberikan gagasan untuk memperbaiki jalannya pembelajaran. Beberapa kelemahannya adalah tentang validitas hasil asesmen yang dilakukan. Pelaksanaan asesmen formatif informal tergantung pada ketrampilan komunkasi guru di kelas. Siswa seringkali juga tidak merasakan kegiatan asesmen. Asesmen formatif informal juga dipengaruhi oleh prasangka tersembunyi guru dan juga stereotipi utamanya stereotipi gender.

Asesmen diagnostik menupakan bagian dari asesmen formatif yang diarahkan pada tipe keputusan diagnostik. Nitko (1989: 50) menjelaskan bahwa keputusan diagnostik menunjuk pada penentuan luaran pembelajaran yang mana siswa belum mencapai dan kemungkinankemungkinan penyebab kegagalan mencapai luaran pembelajaran tersebut. Keputusan diagnostik ini selanjutnya dapat digunakan untuk melakukan remediasi, mengoreksi pengetahuan yang tidak lengkap, dan memperbaiki pembelajaran sebelumnya.

Asesmen diagnostik dapat pula didefinisikan sebagai asesmen formatif yang digunakan untuk mengetahui kelemahan-kelemahan siswa dalam mempelajari suatu materi. A sesmen diagnostik juga memfokuskan pada kesulitan yang dialami oleh siswa dalam mempelajari suatu konsep. Hasil-hasil asesmen diagnostik dapat dimanfaatkan sebagai dasar untuk menentukan tindakan-tindakan yang tepat berikutnya dalam pembelajaran. Dalam pembelajaran sains dan fisika, asesmen diagnostik juga banyak digunakan untuk mengungkap miskonsepsi yang dialami oleh siswa.

Beberapa karakteristik asesmen diagnostik yang berbeda dengan asesmen formatif yang lain adalah sebagai berikut. (1) Asesmen diagnostik difokuskan untuk mengidentifikasi kesulitan belajar siswa pada topik tertentu dan menemukan penyebab mengapa kesulitan-kesulitan belajar ini terjadi. (2) A sesmen diagnostik dikembangkan berdasarkan analisis sumbersumber kesalahan dan kesulitan yang mungkin timbul. (3) Jika dilakukan secara formal, biasanya digunakan format jawaban singkat agar dapat menjangkau jumlah siswa yang besar dan mudah di analisis. Jika menggunakan format pilihan ganda digunakan distraktor dan alasan untuk dapat memetakan kesulitan belajar dan penyebab-penyebabnya. (4) Hasil- 
hasil asesmen diagnostik memberikan umpan balik yang jelas bagi guru untuk mengatasi kelemahan-kelemahan siswa dalam pembelajaran.

Penelitian pengembangan model AAFF ini merupakan pengembangan dan pengayaan penelitian yang dilakukan sebelumnya. Pengembangan butir pilihan ganda dengan mengoptimumkan pengecoh banyak mendapatkan perhatian berkaitan dengan upaya untuk mendeteksi kelemahan dan kekuatan siswa. Butir pilihan ganda ini sering disebut dengan pilihan ganda dengan pengecoh yang tersusun secara bermakna (distractor rationale taxonomy). Pengembangan butir pilihan ganda dengan pengecoh yang bermakna dimaksudkan untuk membantu guru mendiagnosis konsepsi siswa. Teknik yang digunakan adalah dengan memilih pengecoh yang mewakili kesalahan umum yang sering dilakukan oleh siswa. Penggunaan tes pilihan ganda dengan pengecoh yang bermakna untuk mendapatkan laporan tentang tingkat pemahaman siswa telah dilaksanakan untuk matapelajaran matematika dan bahasa (King et al, 2004). Penggunaan item pilihan ganda tersusun (ardared miltiple dhice) juga telah diterapkan pada matapelajaran bahasa (Lin et al, 2010).

Pengembangan butir pilihan ganda dengan pengecoh yang bermakna memiliki potensi besar untuk membantu guru mendapatkan informasi kelemahan dan kekuatan siswa dalam mempelajari konsep. Namun demikian, pengembangan ini belum banyak didukung oleh laporan pengembangan perangkat analisis yang secara praktis dapat dimanfaatkan oleh guru. Upaya pemanfaatan teori respon butir untuk menganalisis butir pilihan ganda diantaranya dilakukan untuk menentukan kemajuan pemahaman konsep dan perubahan konsep (Sadler, 1998). Namun demikian pemanfaatan hasil analisis untuk memberikan informasi pada guru dan umpan balik bagi siswa belum banyak dilaporkan.

Beberapa laporan penelitian menunjukkan adanya upaya melakukan analisis asesmen diagnostik dan mendapatkan informasi diagnostik untuk keperluan pembelajaran. Proyek DIAGNOSER implementasi asesmen berbasis internet yang adalah melaporkan tentang pengembangan instrumen dan perangkat analisis asesmen berbantuan komputer untuk membangkitkan informasi diagnostik dan umpan balik (ThissenRoe\&Hunt, 2004). D alam D IAG NO SER ini digunakan teknik facet untuk 
mengidentifikasi tingkat pemahaman konsepsi siswa. Salah satu kekurangan D IAG SO SER adalah kesulitan pengembangan instrumen dengan teknik facet. Pemanfaatan hasil asesmen untuk mempengaruhi proses pembelajaran Akuntansi yang dikenal dengan AnAmalysis of DiagnosticExam Driven Teahing and Leaming (ADEPT leaming gde) juga telah dilaporkan (Shoulder\&Hicks, 2008). Dalam laopran penelitian ini pembelajaran mengimplementasikan tes diagnostik dan menerapkannya untuk menentukan langkah yang diambil dalam proses pembelajaran akuntansi. Penelitian menunjukkan bahwa pembelajaran yang dikembangkan terbukti efektif dan memuaskan mahasiswa.

Penelitian tentang penggunaan butir pilihan ganda untuk mendapatkan tingkat kelemahan pemahaman konsep Fisika Dasar telah dilakukan (O baidat\&Malkawi, 2009). Disebutkan bahwa analisis tradisional butir pilihan ganda dengan fokus pada skor dan korelasi jawaban benar tidak dapat secara optimal memberikan informasi yang dibutuhkan oleh guru. Peneliti menggunakan persamaan faktor konsentrasi (concentration factor) dan menggabungkannya dengan skor untuk mendapatkan analisis pada setiap pertanyaan. Penelitian ini menunjukkan bahwa pemahaman siswa pada materi kinematika dan Hukum Newton tentang gerak siswa lemah. Penelitian tidak melaporkan adanya umpan balik yang disampaikan pada siswa.

Beberapa penelitian dan kajian lain tentang upaya untuk meningkatkan kualitas asesmen formatif dalam pembelajaran adalah sebagai berikut.

1. Perangkat lunak IMMEX, didesain sebagai alat untuk memahami strategi pemecahan masalah oleh siswa. Dalam menggunakan IMMEX, siswa dikenalkan dengan masalah dan tujuan pemecahan masalah. Selanjutnya siswa memilih penyataan-pernyataan berkaitan dengan upaya mereka memecahkan masalah. Umpan balik langsung akan diberikan berkaitan dengan pilihan siswa. Guru akan memperoleh peta dan jalur pemikiran siswa dalam memecahkan masalah. Pengunaan IMMEX telah dilaporkan dalam perkuliahan laboratorium organik dan terbukti dapat meningkatkan kemampuan pemecahan masalah mahasiswa (Cox jr. et al, 2008). 
2. Dufresne\&G erace (D ufresne\&G erace, 2004) melaporkan inovasi A2L yang menggunakan bahan asesmen formatif dengan menggunakan sistem komunikasi kelas. Sistem ini merupakan aplikasi asesmen formatif informal yang dapat mempresentasikan permasalahan, mengumpulkan dan menyimpan jawaban setiap siswa, menampilkan histogram respon siswa, dan menyimpan secara permanen kemajuan masing-masing siswa. Pemanfaatan A2L dapat menggeser pelaksanaan asesmen formatif menjadi lebih berpusat pada siswa. A sesmen ini juga memungkinkan guru mengetahui proses mental siswa-siswanya.

3. TheOnlineAssessment Desain and Deivery System(AD D S) adalah sebuah sistem desain dan implementasi asesmen berbasis intemet (Vendlinski et al, 2008). Pengembangan sistem berbasis internet ini dimaksudkan untuk secara berkesinambungan meningkatkan kualitas pelaksanaan asesmen formatif. Instrumen dalam sistem ini memanfaatkan prekonsepsi dan miskonsepsi siswa. Pemanfaatan sistem ini menunjukkan kelebihan yaitu kemampuan mendeteksi kemampuan siswa dalam tingkatan yang mendalam. Sistem ini meningkatkan waktu yang dibutuhkan guru dalam menyusun instrumen.

4. Penggunaan Computer Aided Assessment (CAA) disimpulkan dapat menimbulkan dampak positif pada pengalaman belajar siswa (Lowry, 2005). Data menunjukkan bahwa penggunaan CAA sebagai asesmen mandini berdampak positif pada siswa. Bagi guru, CAA sangat berperan dalam menghemat waktu. Sementara bagi siswa, sistem CAA ini dapat memberikan beberapa keuntungan. (1) memberikan umpan balik pada siswa, (2) membimbing usaha-usaha siswa, (3) mendiagnosa permasalahan dalam pembelajaran, dan (4) memberikan pengalaman pada siswa dalam kegiatan asesmen mandiri. Penelitian lain tentang implementasi CAA untuk meningkatkan regulasi diri juga telah diterapkan untuk penulisan esay di perguruan tinggi (Bose\&Rengel, 2009).

5. Spesific Mathematic Assessment that Revel Thinking (SMART) adalah proyek pengembangan dan penelitian sistem asesmen formatif matapelajaran matematika (Stancey at al, 2009). Tujuan dani proyek ini adalah untuk (1) mempermudah pengembangan tes yang mampu 
mendianosa pemahaman konsep siswa, (2) mengembangkan informasi untuk guru tentang kinerja kelas dan individu, (3) memberikan saran pembelajaran, dan (4) memberikan dukungan riset terhadap hasil diagnosis dan saran yang diberikan. Proyek sedang mengujicobakan tes dan melakukan evaluasi terhadap pembelajaran yang dilakukan oleh siswa.

6. Dalam konteks penelitian di Indonesia, beberapa penelitian untuk mengembangkan asemen for leamingtercatat dilakukan diantaranya oleh Wasis (2009) tentang skoring pada respon miltiple truefalse dan Suratno (2009) model asesmen teman sejawat (ATS) pada latar pengelolaan pola belajar kolaboratif (PBK) disingkat menjadi model ATS-PBK. Warsito (2010) juga telah melakukan perintisan pengembangan model analisis tes untuk keperluan peningkatan prestasi belajar siswa.

Salah satu inovasi yang dapat diajukan untuk meningkatkan kualitas pelaksanaan asesmen formatif adalah dengan mengembangkan model analisis asesmen formatif fisika. Pengembangan model analisis asesmen formatif ini meliputi pengembangan model analisis yang secara efektif menghasilkan informasi tentang kekuatan dan kelemahan siswa dalam belajar fisika disertai pengembangan instrumen asesmen formatifnya. Peta informasi kekuatan dan kelemahan belajar fisika siswa dalam satu kelas sering disebut dengan profil kelas. Profil kelas dapat dimanfaatkan guru untuk mengambil keputusan tindak lanjut pembelajaran. Profil individual merupakan umpan balik bagi setiap individu siswa, hal ini berguna bagi siswa untuk memperbaiki strategi belajamya.

\section{Metode Penelitian}

Penelitian tentang analisis asesmen formatif fisika (AAFF) SMA berbantuan komputer ini menggunakan metode penelitian pengembangan (rearch and dedepment). Model pengembangan yang diikuti adalah model pengembangan desain pembelajaran yang dikemukakan oleh Dick dan Carey. Dalam model desain pembelajaran ini, siklus pengembangan terdiri atas 5 (lima) fase yakni: (1) fase analisis kebutuhan (need analysis), (2) fase 
analysis front-end (front-end analysis) (3) fase desain (dksig), (4) fase pengembangan (dedepment), dan (5) fase implementasi (implementation), dan (5) fase evaluasi (ealuation).

Penelitian dilaksanakan di beberapa Sekolah Menengah Atas di Kota Malang mulai Maret 2010 sampai dengan Agustus 2010. Sebagai validator dalam pengembangan adalah kelompok diskusi guru fisika yang terdiri dari 6-8 orang guru fisika dari beberapa sekolah menengah yang berbeda. Sebagai tim validasi produk dilibatkan beberapa pakar pengembangan instrumen, pakar penilaian pendidikan, dan pakar pembelajaran fisika. Guru SMA yang tergabung dalam MGMP Fisika juga dilibatkan untuk memberikan masukan pada produk yang telah dikembangkan. Implementasi lapangan dilakukan dengan melibatkan tujuh kelas fiska dari tujuh sekolah yang berbeda. Untuk mengetahui efektivitas balikan yang dihasilkan oleh perangkat lunak yang dikembangkan, balikan diimplementasikan pada 3 kelas dari 3 sekolah yang berbeda. Data-data yang didapatkan sebagian besar dianalisis dengan analisis deskriptif kuantitatif.

\section{Pembahasan}

Hasil pengembangan produk akhir penelitian pengembangan adalah sebuah perangkat lunak AAFF. Perangkat lunak terbagi atas dua bagian utama yaitu bagian desain tes dan bagian hasil analisis. Bagian desain tes berguna untuk memasukkan berbagai data tentang tes yang dilaksanakan dan data respon siswa, sedangkan bagian hasil analisis terdiri dari beberapa jendela hasil analisa yang dapat ditampilkan di layar dan juga dapat di cetak. Berikut adalah contoh halaman sampul AAFF.

Profil kelas memberikan informasi tentang pencapaian keseluruhan siswa pada semua hasil tes. Profil siswa memberikan informasi penampilan masing-masing siswa pada tes. Analisis indikator menunjukkan penampilan siswa pada masing-masing indikator. Semua hal ini memberikan informasi tentang kelemahan dan kekuatan siswa berkaitan dengan materi tes, informasi yang diperlukan guru dalam pembelajaran. Pada bagian profil kelas ini, guru dapat mengamati hasil analisis untuk setiap indikator 
Jumal Penditian danEvaluasi Penddikan

sebagaimana gambar berikut.

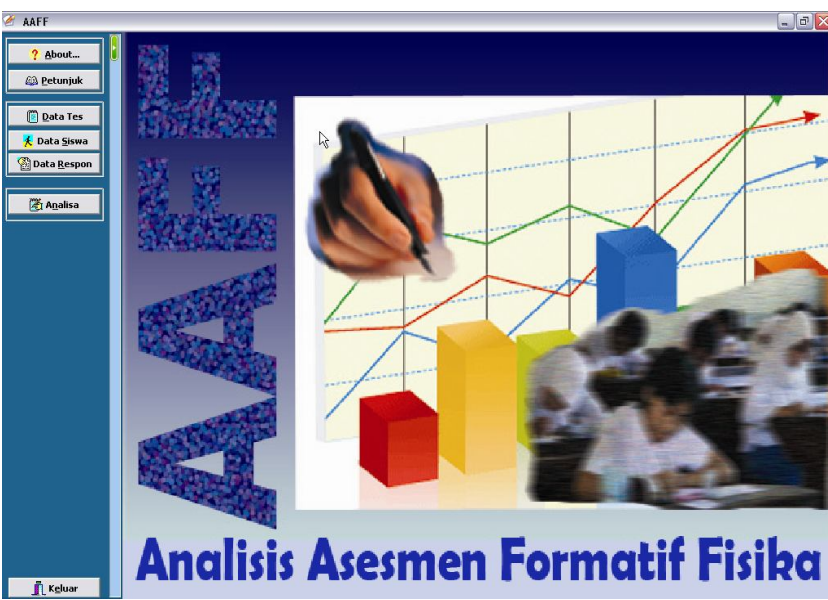

Gambar 1. Tampilan Jendela Muka AAFF

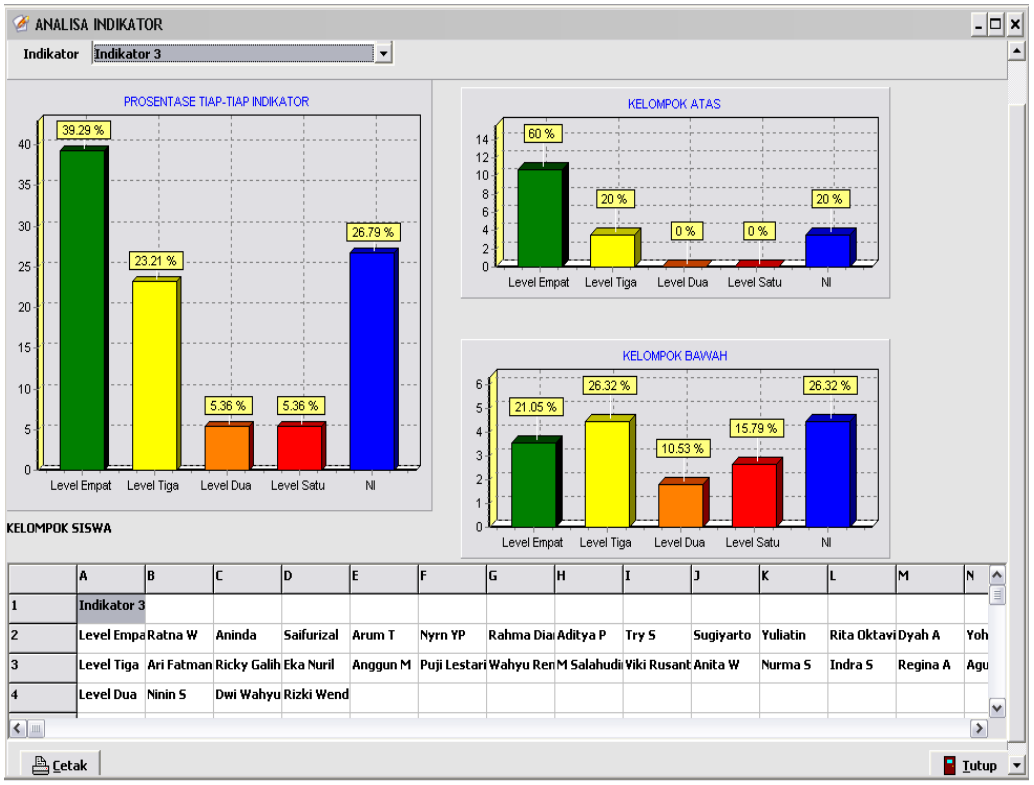

Gambar 2. Contoh Hasil Analisis AAFF untuk Sebuah Indikator

80 - Jumal PenditiandanEvaluasi Pendidkan Edisi D ies Natalis ke-48 UNY 
Keluaran AAFF berupa lembar umpan balik hasil tes dapat dicetak untuk memberikan balikan kepada siswa tentang kelemahan dan kekuatannya dalam pembelajaran. Berikut adalah bentuk umpan balik pada siswa.

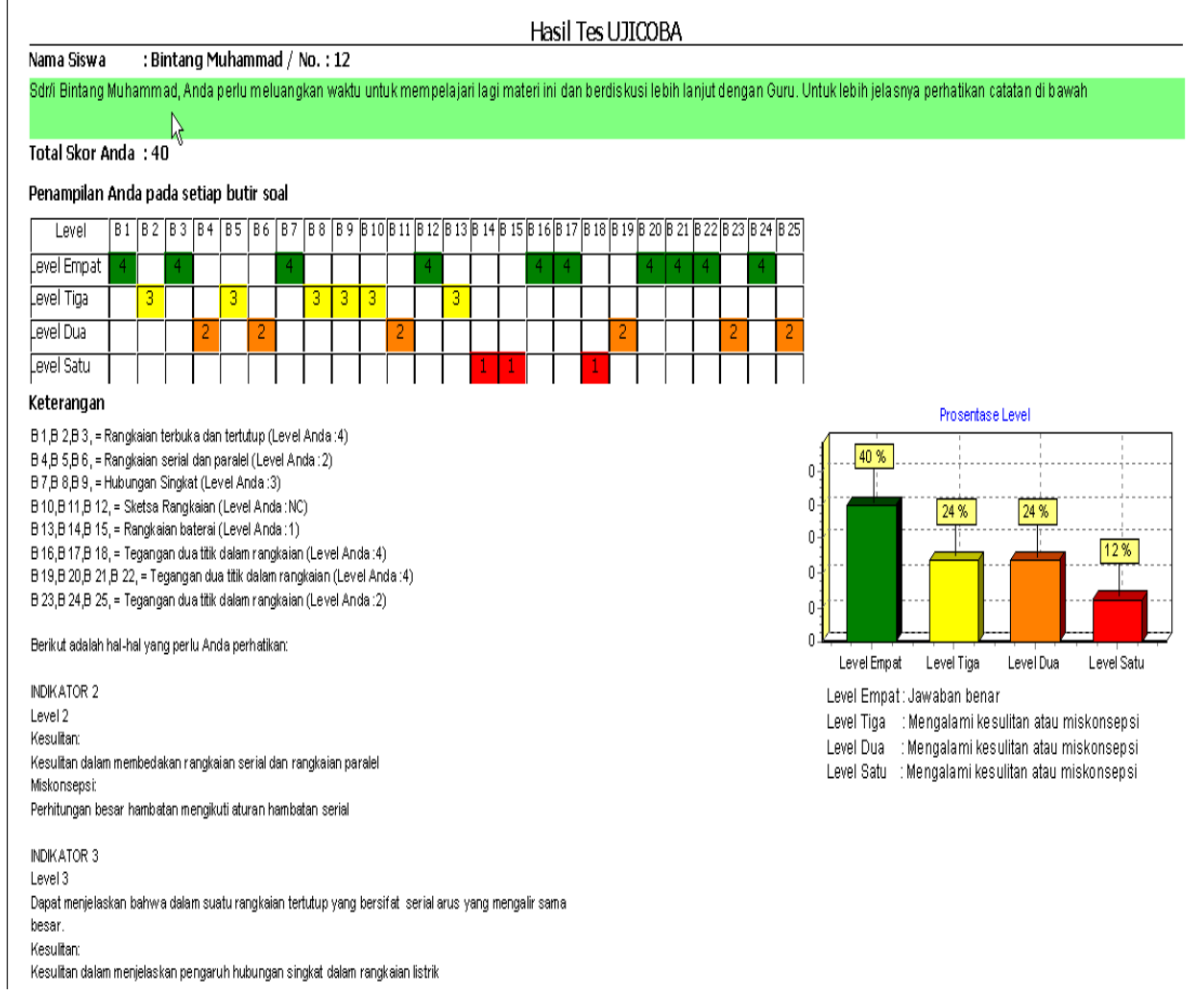

Gambar 3. Contoh Umpan Balik Hasil Belajar Siswa

Model analisis asesmen formatif fisika yang dikembangkan dalam penelitian ini memiliki ciri-ciri khas yang berbeda dengan perangkat lunak yang lain. Beberapa karakteristik model analisis AAFF adalah sebagai berikut: (1) Model AAFF ditujukan untuk menggali kelemahan dan kesulitan belajar siswa berkaitan dengan materi pembelajaran dan memberikan umpan balik pada siswa tentang hasil tes. Model kelemahan 
dan kesulitan dinyatakan dalam level yang terdapat deskniptornya; (2) Model AAFF hanya cocok digunakan untuk tes pilihan ganda dengan persyaratan tertentu diantaranya pengecoh memiliki makna dan dapat dijabarkan deskriptornya dan tes terdiri atas beberapa kelompok butir dengan indikator tertentu; (3) Jumlah butir dengan indikator yang sama yang dipergunakan sebagai masukan model AAFF sebaiknya ganjil; (4) Hasil analisis AAFF dapat ditampilkan secara visual dan dicetak; (5) Model AAFF dapat menghasilkan pengelompokan siswa berdasarkan kesulitan belajar atau siswa yang menderita miskonsepsi tertentu.

Model AAFF memiliki beberapa keunggulan, keunggulankeunggulan tersebut antara lain adalah sebagai berikut: (1) Model AAFF menghasilkan keluaran berupa profil kelas dan profil siswa yang menunjukkan kelemahan dan kekuatan siswa dalam penguasaan materi pembelajaran baik secara klasikal maupun individual; (2) Model AAFF menghasilkan keluaran dalam bentuk umpan balik hasil belajar siswa untuk masing-masing siswa; (3) Model AAFF menghasilkan keluaran pengelompokan siswa berdasarkan penampilan pada suatu butir dan pada suatu indikator, (4) Pemanfaatan AAFF dalam pembelajaran fisika akan membantu guru mengambil keputusan tentang perencanaan pembelajaran yang efektif dan remediasi yang lebih terarah; (5) Implementasi umpan balik dapat memberikan gambaran pada siswa tentang kelemahan dan kekuatannya dalam penguasaan materi pembelajaran, memotivasi belajar siswa, dan memberikan arahan belajar yang lebih efektif; (6) Pengelompokan siswa berdasarkan kelemahan dan kekuatannya dapat dimanfaatkan untuk mengelola tugas-tugas belajar yang lebih efektif.

Hasil analisis memberikan informasi tentang kondisi siswa untuk setiap kelas. Informasi yang dihasilkan bergantung pada kondisi siswa di kelas tersebut. Hal ini dapat membantu guru dalam melakukan tindak lanjut pembelajaran seperti memberikan remedial. Gambar berikut merupakan hasil analisis dari kelas yang berbeda. 


\section{PROFIL KELAS}

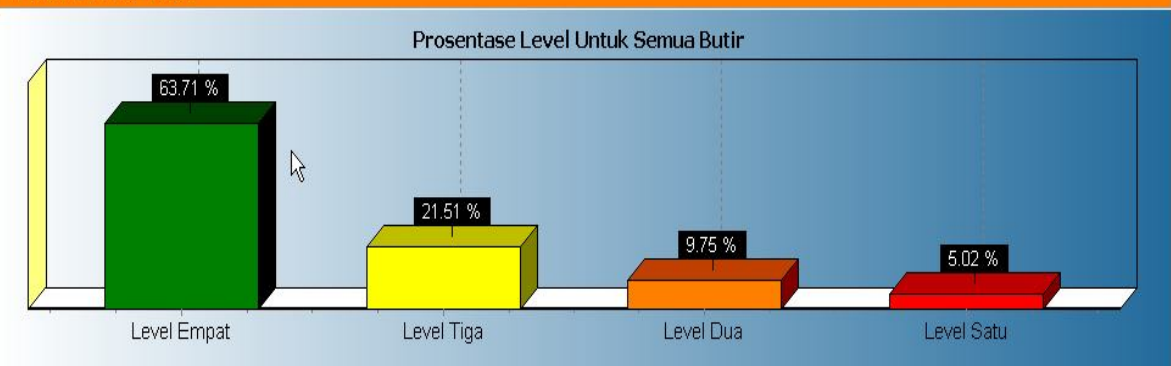

\section{PROFIL KELAS}

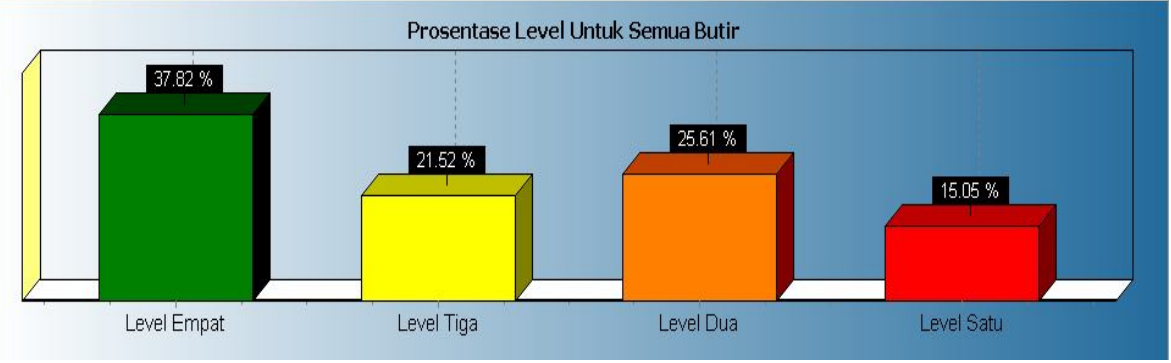

Gambar 4. Hasil Profil Kelas untuk 2 Kelas yang Berbeda

Beberapa kelemahan produk yang dihasilkan diantaranya adalah (1) Model AAFF tidak dapat digunakan secara langsung dengan memanfaatkan tes pilihan ganda yang telah tersedia di sekolah. Perlu adanya modifikasi soal yang tersedia untuk dapat memanfaatkan secara optimal AAFF (2) Kualitas hasil analisis model AAFF bergantung pada kualitas tes pilihan ganda yang digunakan. (3) Model AAFF mensyaratkan agar semua butir soal dijawab oleh siswa dan tidak memungkinkan siswa mengosongi jawaban. (4) Penyusunan tes pilihan ganda dengan persyaratan khusus model AAFF menyulitkan guru, membebani tugas guru, dan menyita banyak waktu. (5) Penyusunan data tes AAFF memerlukan kecermatan dan memerlukan waktu. (6) Penggunaan model AAFF membutuhkan kemampuan ketrampilan dasar komputer.

Terkait dengan kemanfaatan hasil analisis AAFF dalam pembelajaran, sebagian responden guru menyatakan bahwa hasil analisis 
sangat bermanfaaf untuk mengambil keputusan berkaitan dengan pembelajaran. Siswa juga merupakan salah satu pihak yang mendapatkan manfaat dari pengembangan model AAFF ini. Berkaitan dengan umpan balik hasil belajar yang dibagikan kepada siswa, sebagian besar siswa menyatakan bahwa umpan balik sangat bermanfaat untuk mengetahui hasil belajar dan merencanakan belajar berikutnya. Komentar siswa sebagian besar menyatakan bahwa model AAFF dapat membantu mereka mengetahui kekuatan dan kelemahan belajar fisikanya. Grafik berikut menunjukkan pendapat guru dan siswa tentang kemanfaatan AAFF.

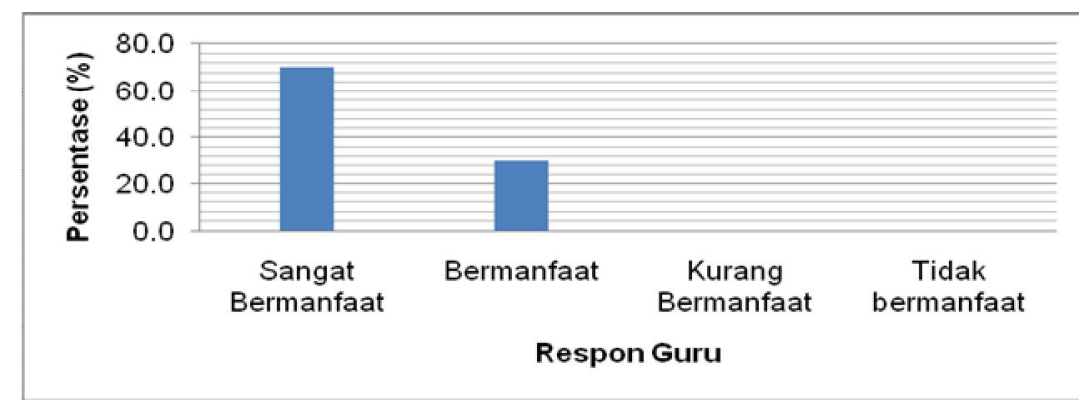

G ambar 5. G rafik Kemanfaatan AAFF untuk Membantu Mengambil Keputusan tentang Pembelajaran

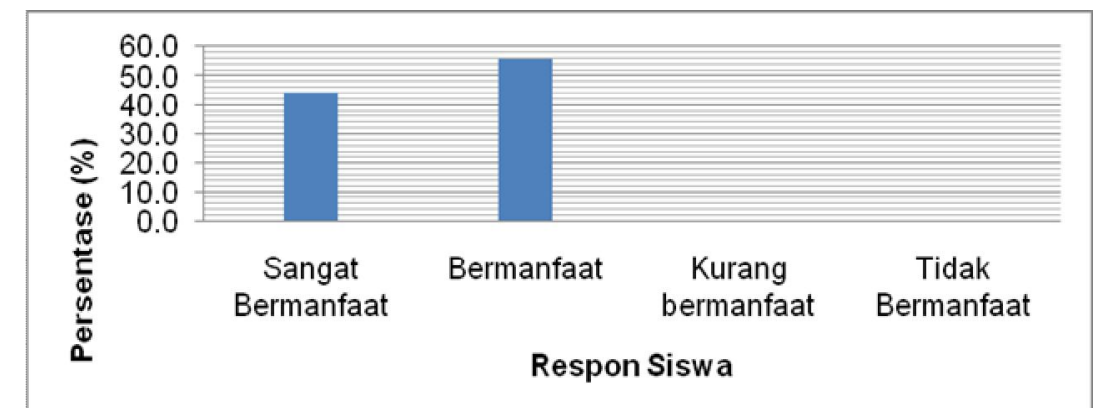

Gamabar 6. Grafik Pendapat Siswa tentang Kemanfaatan AAFF untuk Memahami Hasil Belajar

84 - Jumal Penditian danEvaluasi Pendidkan Edisi D ies Natalis ke-48 UNY 


\section{Kesimpulan dan Saran}

Penelitian ini telah berhasil mengembangkan dan menguji kelayakan AAFF dalam membantu guru menganalisis asesmen formatif dan memberikan umpan balik kepada siswa secara lebih efektif dan efisien. Mengingat produk yang dihasilkan membutuhkan instrumen yang khusus, disarankan adanya kegiatan lanjutan untuk mengembangkan butir soal yang sesuai. Kepada guru-guru SMA khususnya guru-guru fisika, disarankan untuk memanfaatkan AAFF sebagai perangkat untuk menganalisis hasil tes pilihan ganda. Penelitian lanjutan disarankan juga dilakukan untuk menguji secara lebih luas dan menyempurnakan pengembangan perangkat lunak yang telah dilakukan.

\section{Daftar Pustaka}

Anderson, L. W., (2003). Clasroom Assessment: enhancing the quality of teacher decision making,New Jersey: Lawrence Erlbaum Associates, Inc

Bose, J. ,\& Rengel Z. (2009) A model formative assessment strategy to promote student-centered self-regulated learning in higher education[versi elektronik]. US-China Education Review 6 (12).

Boyle, J. \& Fisher, S. (2007). Educational TestingA CompetenceBased Apprach Victoria: British Psycological Society.

Cowie, B. \& Bell, B. (1999). A model of formative education in science education. Assessmentin education Maret 1999, 6, 1.

Cox Jr. C. T, Cooper M. M., Pease R, Buchanan K, Hernandez-Cruz L., Stevens R, Picione Thomas Holme T., (2008). Advancements in curriculum and assessment by the use of IMMEX technology in the organic laboratory[ versi elektronik]. Chem Educ Res Prad., 2008, 9, 25-34 
Jumal Penditian danEvaluas Pendidikan

Dufrese, R. J. \& GeaceW. J., (dktdber 2004). A ssessing-To-Learn: Formative Assessment in Physics Instruction. THE PHYSICS TEACHER Vol. 42, O ctober 2004, 428-433

King, K. V., Gardner, D . A., Zucker, S., Jorgansen, M. A. July 2004, The Distractor Rationale Taxonomy: Enhancing Multiple-Choice Items in Reading and Mathematics Pearson Education

Lin, J., Chu, K., Meng, Y., April 30, 2010 D istractor Rationale axonomy: Diagnostic Assessment of Reading with Ordered Multiple-Choice Items.http:// www.pearsonassessments.com/ NR/ rdonlyres/ 134E 0794-E59A4F05-A 495EAF600468792/ 0/ LinJie D istractorrationaleAERA Paper 51010.pdf

Lowry, R. (2005). Computer aided self assessment: An effective tool. Chemistry Education RerchandPractice 2005, 6 (4), 198-203

Nitko, A. J. (1989). Designing teet that areintegrated with instruction: Edurational mesurement, London: Collier Macmillan Publisher,

O baidat I.\& Malkawi E. (2009). The G rasp of physics concepts of motion: Identifying particular pattems in students' thinking. Intemational Jarmal for theSdhdarship of TedingandLeming 3(1), 1-16

Popham, W. J. (1995). Classrom Assessment: What Teadhers Need to Know Boston: Allyn and Bacon.

Popham, W. J. (2008). Transfomative Assessment, Virginia: Ascociation of supervision and curricullum development (ASCD).

Shoulders, C. D., Hicks, S. A. (2008). ADEPT learning cycles enhance intermediate accounting student learning success [versi electronik]. IssuesinAcauntingEduration, 23, 2, 161-182.

Stacey, K., Price, B., Steinle,V.,Chick, H., Gvozdenko, E. (2010) SMART Assesment for LemingISDDE conferene2009

Suratno, 2009, Pengembangan Model Asesmen Teman Sejawat Kompetensi Akuntansi Berbasis Model Pembelajaran Kolaboratif, Disertasi Tidak diterbitkan.Universitas Negeri Y ogyakarta.

86 - Jumal PenditiandanEvaluas Pendidkan Edisi D ies Natalis ke-48 UNY 
Thissen-Roe, A., Hunt E, Minstrell, J. (2004). The D IAG NO SER project: Combining assessment and leaming [versi elektronik], Behavior Reserch Methods Instruments, \& Computers 2004, 36 (2), 234-240

Vendlinski, T. P., Niemi, D. M. Wang, J., Monempour, S., Juli 2008., Improving Formative Assessment Practice with Educational Information http:/ / www.cse.ucla.edu/ products/ reports/ R739.pdf Technology

Warsito, 2010, Pengembangan Model Analisis Prestasi Belajar untuk Mengidentifikasi Kesulitan Belajar Peserta Didik, Disertasi Tidak diterbitkan, Universitas Negeri Padang.

Wasis, 2009, Model Penskoran Partial Credit Pada Item Multiple True False Bidang Fisika, D isertasi Tidak diterbitkan, Universitas Negeri Yogyakarta. 